
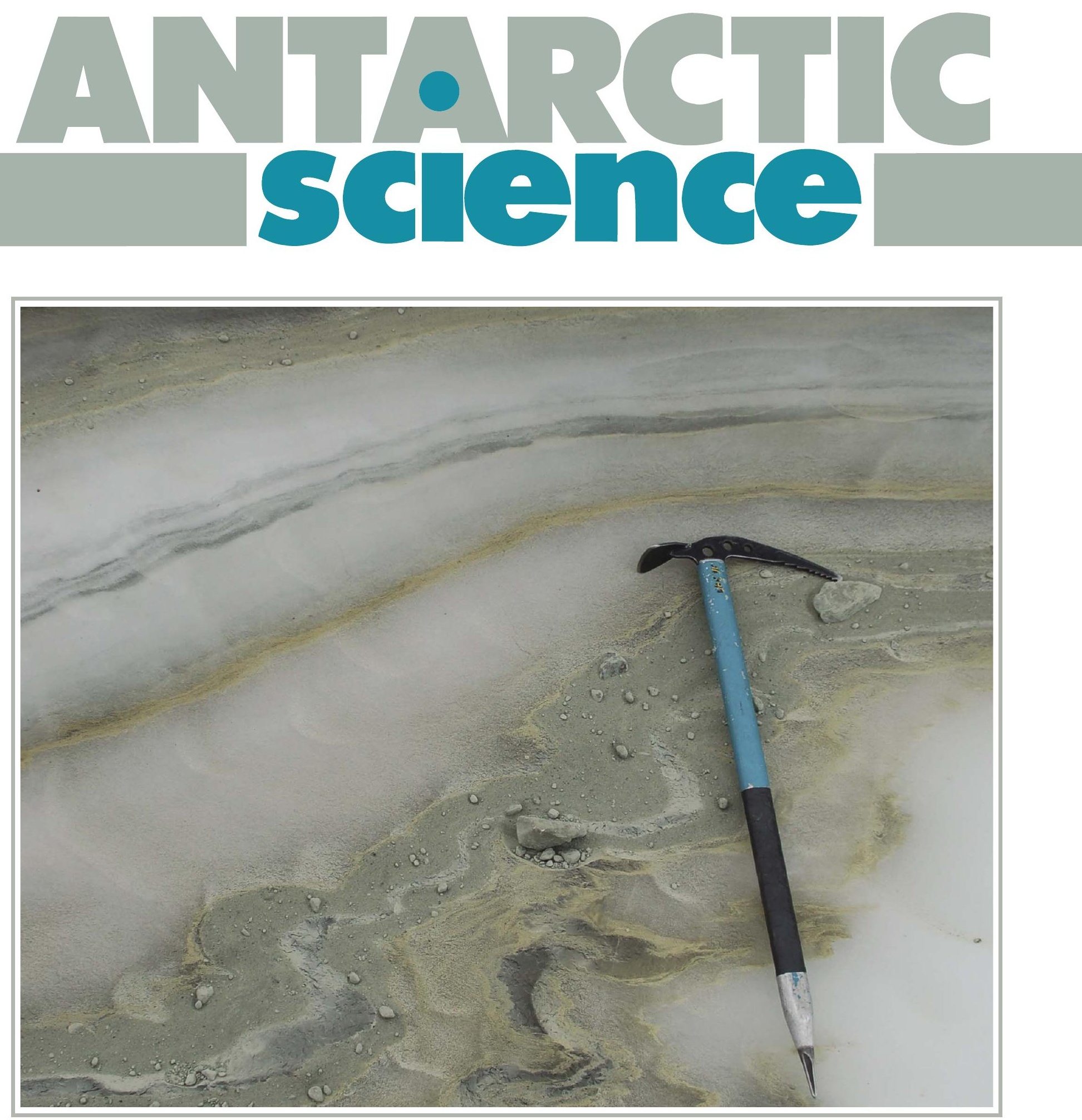

VOLUME 26 NO 2 APRIL 2014

ISSN 09541020

CAMBRIDGE UNIVERSITY PRESS
- BIOLOGICAL SOIL CRUSTS

- HEAT SHOCK IN MARINE INVERTEBRATES

- ALBATROSS AND GIANT PETRELS AT GOUGH

- WATER TRACKS IN SOIL ECOSYSTEMS

- SEDIMENTS AND EAST ANTARCTIC ICE SHEET

- MEASURING TEMPERATURE PROFILES WITH UAVS 


\section{AN science}

\section{EDITORS}

David W.H. Walton

Life Sciences

Walker O Smith

Marine Sciences

wos@vims.edu

Laurie Padman

Physical Oceanography and Glaciology

padman@esr.org

Alan Rodger

Atmospheric Sciences

John Smellie

Earth Sciences

jls55@le.ac.uk

\section{MANAGING EDITOR}

Sharon Cooke

\section{EDITORIAL OFFICE}

British Antarctic Survey (NERC)

High Cross, Madingley Road,

Cambridge CB3 0ET, UK.

antarctic.science@bas.ac.uk

\section{COVER}

Sediment layers in debris-rich basal ice of the Koettlitz Glacier, western Ross Sea. Glaciers such as this one transport material eroded from the Transantarctic Mountains and from the bed of the East Antarctic Ice Sheet, finally depositing it as moraines and drift sheets along the flanks of the McMurdo Dry Valleys. (Photo Dr Nicholas Golledge)

\section{EDITORIAL ADVISORY BOARD}

D. Barnes, British Antarctic Survey, UK

M. Brix, Ruhr-Universität Bochum, Germany

D. Cantrill, National Herbarium of Victoria, Australia

Y. Cherel, Centre d'Etudes Biologiques de Chizé, France

S.L. Chown, University of Stellenbosch, South Africa

J.T. Eastman, Ohio University, USA

F. Florindo, Istituto Nazionale di Geofisica e Vulcanologia, Italy

C. Fogwill, University of Exeter, UK

L. Gimeno, Universidad de Vigo, Spain

D. Gore, Macquarie University, Australia

K. Hall, University of North British Colombia, Canada

E. Hofmann, Old Dominion University, USA

C. Howard-Williams, NIWAR, New Zealand

D.R. Marchant, Boston University, USA

S.D. Matheos, Universidad Nacional de La Plata, Argentina

R. Muench, Earth \& Space Research, USA

B. Njåstad, Norwegian Polar Institute, Norway

F. Pattyn, Vrije University Brussels, Belgium

A.S. Rodger, British Antarctic Survey, UK

P. Ryan, University of Cape Town, South Africa

E. Surinach, Universitat de Barcelona, Spain
Editorial Policy. Antarctic Science provides a focus for many of the interdisciplinary interests that characterize Antarctic studies. The journal includes both synthesis and data papers, opinion papers, short notes on technical developments and field work, an editorial and book reviews. Antarctic Science is a journal that is interesting, original and topical yet rigorous in its treatment of primary scientific data. There is no maximum page length for scientific papers. Authors are required to follow the style set out in 'Instructions for Contributors' accessible either as a pdf at journals.cambridge.org/ans or through http:// mc.manuscriptcentral.com/cup/antsci where all manuscripts must be submitted.

Ownership. Antarctic Science is owned by the charitable company Antarctic Science Ltd (Directors: J.R. Dudeney, J.E. Francis, K. Hendry, T. Jickells, M.R.A. Thomson, P.A. Tyler, D.W.H. Walton) Registered Charity no: 1090581. Registered Office: Antarctic Science Ltd, Mills \& Reeve, 112 Hills Road, Cambridge CB2 1BH.

Subscriptions. Antarctic Science ISSN 0954-1020, is published bimonthly in February, April, June, August, October and December, six parts form a volume, by Cambridge University Press, The Edinburgh Building, Shaftesbury Road, Cambridge, CB2 8RU, UK/Cambridge University Press, 32 Avenue of the Americas, New York, N.Y. 10013-2473. The subscription price of volume 26 (2014) (which includes postage) is $£ 648$ net (USA, Canada and Mexico US\$1248) for institutions print and electronic; institutions electronic only $£ 495 / \$ 962$, and $£ 143$
(USA, Canada and Mexico US\$281) for individuals print. Single parts cost $£ 109.45$ (USA, Canada and Mexico US\$212.11) plus postage, unless purchased in bulk. Orders, which must be accompanied by payment, may be sent to the bookseller, subscription agent or direct to the publisher: Cambridge University Press, The Edinburgh Building, Shaftesbury Rd, Cambridge CB2 8RU; or in the USA, Canada and Mexico: Cambridge University Press, Journals Fulfillment Department, 100 Brook Hill Drive, West Nyack, New York 10994-2133. EU subscribers (outside the UK) who are not registered for VAT should add VAT at their country's rate. VAT registered subscribers should provide their VAT registration number. Japanese prices for institutions are available from: Kinokuniya Company Ltd., PO Box 55, Chitose, Tokyo 156, Japan.

Prices include delivery by air where appropriate. Copies of the journal for subscribers in the USA, Canada and Mexico are sent by air to New York. Periodicals Postage paid at New York, NY and additional mailing offices.

POSTMASTER: Send address changes to Antarctic Science, Cambridge University Press, 100 Brook Hill Drive, West Nyack, N.Y. 10004-2133.

For further information on Antarctic Science or other Press titles access journals.cambridge.org

(C) Antarctic Science Ltd 2014 